\title{
Pengaruh Leverage, Likuiditas, Profatibilitas, Konservatisme dan Ukuran Perusahaan terhadap Kualitas Laba
}

\author{
Lutfiana Rezky Anggraeni ${ }^{1}$, Listyorini Wahyu Widati ${ }^{2}$ \\ Universitas Stikubank Semarang, Indonesia \\ lutfianarezky9999@gmail.com, listyorini@edu.unisbank.ac.id
}

*Corresponding Author

$\begin{array}{ll}\text { Diajukan } & : 10 \text { Desember } 2021 \\ \text { Disetujui } & : 17 \text { Desember } 2021 \\ \text { Dipublikasi } & : \text { 1 Januari } 2022\end{array}$

ABSTRACT

Earnings quality is earnings that correctly and accurately describes the company's operational profitability. Earnings quality in a company is very important to be analyzed. Companies that have high earnings quality will provide complete and transparent information and will not mislead users of financial statements. This study aims to determine and analyze the effect of leverage, liquidity, profitability, conservatism and firm size on earnings quality. at companies registered in Indonesia Stock Exchange (IDX) in 2017 to 2020. The population in this study are all manufacturing companies that have been listed on the Indonesia Stock Exchange (IDX) for the period 2017 to 2020, obtaining a population of 704 companies. This research method uses purposive sampling, the sample was obtained in accordance with predetermined criteria and obtained data as many as 326 companies. The type of data used in this research is secondary data. The analytical technique used in this research is multiple linear regression analysis. This study obtained the results that leverage as measured by (DAR), firm size as measured by (Size), and liquidity as measured by $(Q R)$ have no significant effect on earnings quality. Meanwhile, profitability as measured by (ROA) and conservatism as measured by (CON_ACC) have a significant effect in a positive direction on earnings quality.

Keywords: conservatism; earnings quality; firm size; leverage, liquidity, profitability

\section{PENDAHULUAN}

Laporan keuangan adalah dokumen yang memberikan informasi pencatatan dari segala transaksi yang berkaitan dengan uang, pembelian dan penjualan serta kredit. Laporan keuangan juga berfungsi untuk mengetahui keadaan finansial perusahaan, sehingga laporan yang dibuat dapat secara detail, tepat dan perhitungan yang baik (PSAK No.1 2015:2). Menurut Penman dan Cohen (2003); Wibowo (2009) diungkapkan bahwa laba tahun berjalan memiliki kualitas yang baik jika laba tesebut menjadi indikator yang baik untuk laba masa mendatang, atau berhubungan secara kuat dengan arus kas operasi dimasa mendatang. Sebagai contoh fenomena yang terjadi pada kasus PT Asuransi Jiwasraya (Persero) ketua BPK Agung Firman Sampurna mengatakan Jiwasraya mengalami kerugian sejak tahun 2006. AJS terbukti memanipulasi laporan keuangannya dengan mencatat ada laba, tapi ternyata semu belaka. Tahun 2017, Jiwasraya tercatat membukukan laba sebesar Rp 360,3 miliar, tetapi kemudian mendapat opini adverse. Artinya opini tersebut tidak wajar, akibat adanya kekurangan pencadangan sebesar Rp 7,7 triliun. Tahun 2018, Jiwasraya kemudian membukukan kerugian Rp 15,3 triliun. Kemudian, bulan September 2019, perusahaan diperkirakan rugi Rp 13,7 triliun. Keuangan memburuk hingga November 2019, keuangan perusahaan negatif Rp 27,2 triliun. (cnbncindonesia.com).

Dalam penelitian ini masih terdapat fenomena, research gap, perbedaan objek dan pengukuran yang digunakan peneliti. Peneliti terdahulu menggunakan objek penelitian perusahaan manufaktur barang konsumsi yang terdaftar di Bursa Efek Indonesia (BEI) dan kulitas 
laba diukur menggunakan pendekatan penman (Operating cashflow/aba), sedangkan penulis menggunakan objek penelitian perusahaan manufaktur yang terdaftar di Bursa Efek Indonesia (BEI) dan kualitas laba diukur menggunakan quality of income (arus kas operasi/EBIT). Sehingga penelitian ini bertujuan untuk menguji dan menganalisa pengaruh leverage, likuiditas, profatibilitas, konservatisme dan ukuran perusahaan terhadap kualitas laba pada perusahaan yang terdaftar di Bursa Efek Indonesia tahun 2017 sampai 2020. Penelitian ini diharapkan dapat memberikan manfaat dan informasi yang terkait dengan kualitas laba serta dapat dijadikan sebagai refrensi untuk pengambilan keputusan yang tepat bagi peneliti selanjutnya.

Leverage merupakan rasio untuk mengukur sejauh mana aset perusahaan dibiayai dengan utang. Hasil penelitian terdahulu yang dilakukan oleh Satria Dewi dkk (2020) menyatakan bahwa leverage berpengaruh negatif terhadap kualitas laba perusahaan. Berbeda dengan penelitian yang dilakukan oleh Setiawan (2017) menyimpulkan bahwa leverage tidak berpengaruh signifikan terhadap kualitas laba.

Likuiditas merupakan kemampuan suatu perusahaan untuk memenuhi hutang jangka pendeknya dengan asset lancar yang dimiliki (Irawati, 2012). Hasil penelitian Kurniawan \& Suryaningsih (2018); Ginting (2017) menyatakan bahwa likuiditas tidak memiliki pengaruh positif terhadap kualitas laba. Sedangkan penelitian Zulman \& Abbas (2019) menyatakan bahwa likuiditas berpengaruh positif terhadap kualitas laba.

Profitabilitas menggambarkan kemampuan perusahaan dalam menghasilkan laba melalui sumber daya. Profitabilitas suatu perusahaan dapat diukur dengan melihat perbandingan antara laba dengan asset. Hasil penelitian Ardianti (2018); Kurniawan \& Suryaningsih (2018) menyimpulkan bahwa profitablilitas memiliki pengaruh positif terhadap kualitas laba, sedangkan penelitian yang dilakukan oleh Ginting (2017); Setiawan (2017); Zulman \& Abbas (2019) menyatakan bahwa profitabilitas secara signifikan tidak berpengaruh terhadap kualitas laba.

Konservatisme merupakan sebuah prinsip kehati-hatian dalam mengakui asset dan laba, karena aktivitas ekonomi dan bisnis yang dilingkupi ketidakpastian (Wibowo dalam Gayatri \& Suputra, 2013). Peneliti Pratiwi \& Pralita (2021) memperoleh hasil bahwa konservatisme akuntansi berpengaruh signifikan negatif terhadap kualitas laba. Hasil penelitian ini berbeda dengan Kurniawan \& Suryaningsih (2018) yang menyatakan bahwa konservatisme akuntansi yang berpengaruh positif terhadap kualitas laba.

Ukuran perusahaan merupakan skala yang menunjukkan besar kecilnya perusahaan. Secara umum ukuran perusahaan diproksi dengan total aset. Hasil penelitian Pratiwi \& Pralita (2021); Zulman \& Abbas (2019) menyatakan bahwa ukuran perusahaan berpengaruh signifikan negatif terhadap kualitas laba. Berbeda arah dengan hasil penelitian Setiawan (2017) menyimpulkan bahwa ukuran perusahaan berpengaruh positif terhadap kualitas laba. Sedangkan hasil penelitian Kurniawan \& Suryaningsih (2018) ukuran perusahaan tidak memiliki pengaruh positif terhadap kualitas laba.

\section{Pengaruh Leverage terhadap Kualitas laba}

\section{STUDI LITERATUR}

Menurut Irham (2015:72) leverage adalah mengukur seberapa besar perusahaan dibiayai dengan utang. Berdasarkan teori agensi (agency theory) yang menjelaskan bahwa manajemen akan melakukan tindakan yang menyimpang untuk memaksimalkan kepentingan pribadi dari pihak manajer. Maka dari itu, manajer akan melakukan peningkatan pada hutang perusahaan, bersamaan itu laba perusahaan harus konsisten supaya perusahaan akan dianggap baik dalam melakukan pengelolaan hutangnya. Menurut Irham (2015:72), leverage tinggi pada perusahaan menyebabkan investor kurang percaya pada penyajian laporan keuangan yang dipublikasikan perusahaan. Perusahaan dengan leverage tinggi akan menyebabkan kualitas laba yang rendah. Pernyataan ini sejalan dengan penelitian Yanto \& Metalia (2021); Setiawan (2017) yang menyimpulkan bahwa leverage memiliki pengaruh negatif terhadap kualitas laba.

\section{H1 : Leverage berpengaruh negatif terhadap kualitas laba}

\section{Pengaruh Likuiditas terhadap Kualitas Laba}


Likuiditas merupakan kemampuan untuk mengubah aset menjadi kas atau kemampuan untuk memperoleh kas (Susanti, 2017:88). Berdasarkan teori agensi (agency theory) menjelaskan kemungkinan adanya manajemen laba yang dilakukan pihak manajemen yang kelak akan berpengaruh terhadap pelaporan keuangan yang tidak akurat sehingga menimbulkan laba yang tidak berkualitas. Likuiditas menunjukkan bahwa perusahaan mampu untuk memenuhi kewajiban perusahaan dalam jangka pendek menggunakan dana lancar yang tersedia diperusahaan. Dengan demikian, semakin tinggi nilai likuiditas maka kualitas laba akan semakin tinggi. Pernyataan ini sejalan dengan penelitian Ardianti (2018) likuiditas berpengaruh positif terhadap kualitas laba.

\section{H2 : Likuiditas berpengaruh positif terhadap kualitas laba}

\section{Pengaruh Profitabilitas terhadap Kualitas Laba}

Profitabilitas merupakan rasio untuk menilai kemampuan perusahaan dalam memperoleh laba (profit). Berdasarkan teori agensi (agency theory), mengingat manajemen lebih mengetahui kondisi keuangan perusahaan, sedangkan pemilik menginginkan tingkat profitabilitas yang tinggi untuk perusahaanya. Semakin besar profitabilitas suatu perusahaan yang ditunjukkan oleh tingginya ROA, artinya perusahaan dianggap mampu dalam menghasilkan laba. Sehingga investor akan semakin yakin bahwa berinvestasi diperusahaan tersebut akan menguntungkan. Semakin besar ROA suatu perusahaan maka semakin besar pula tingkat keuntungan yang dicapai oleh perusahaan tersebut, hal ini berarti perusahaan memiliki kualitas laba yang baik. Pernyataan ini sejalan dengan penelitian Ardianti (2018); Kurniawan \& Suryaningsih (2018) membuktikan bahwa profitablilitas berpengaruh positif terhadap kualitas laba.

\section{H3: profitabilitas berpengaruh positif terhadap kualitas laba.}

\section{Pengaruh Konservatisme terhadap Kualitas Laba}

Konservatisme merupakan penentu kualitas laba (Subramanyam \& John, 2010: 92). Berdasarkan teori sinyal menjelaskan tentang pemberian sinyal yang dilakukan oleh manajer. Laporan keuangan yang konservativ memberikan sinyal positif kepada investor mengenai informasi laba yang berkualitas. Konservatisme dapat melindungi investor dari kekeliruan menilai informasi laba yang tinggi, jika penyajiannya tidak sesuai dengan keadaan yang sebenarnya (Putu \& Dewa, 2014). Logika ini di dukung oleh peneliti Kurniawan dan Suryaningsih (2018) yang menyimpulkan bahwa konservatisme akyntansi memiliki pengaruh positif secara signifikan terhadap kualitas laba.

\section{H4 : Konservatisme berpengaruh positif terhadap kualitas laba}

\section{Pengaruh Ukuran Perusahaan terhadap Kualitas Laba}

Ukuran perusahaan merupakan skala yang menunjukkan besar kecilnya perusahaan. Berdasarkan teori akuntansi positif menjelaskan bahwa seorang manajer tentu ingin mendapatkan imbalan yang tinggi. Biasanya besaran bonus dinilai dari besar kecilnya laba perusahaan, sehingga seorang manajer akan berusaha memberikan laporan pendapatan bersih setinggi mungkin untuk mendapatkan bonus yang tinggi. Salah satu caranya adalah dengan memilih dan menentukan kebijakan akuntansi yang bisa meningkatkan laba pada laporan keuangan diperiode tersebut untuk memberikan kesan yang baik dimata investor dan masyarakat. Semakin besar ukuran perusahaan maka kelangsungan usaha perusahaan tersebut akan semakin tinggi dalam meningkatkan kinerja keuangan. Pernyataan ini sejalan dengan penelitian Kurniawan \& Suryaningsih (2018); Setiawan (2017) yang membuktikan bahwa ukuran perusahaan berpengaruh terhadap kualitas laba.

\section{H5 :Ukuran perusahaan berpengaruh positif terhadap Kualitas Laba}

\section{METODE}

Objek pada penelitian ini yaitu perusahaan manufaktur yang terdaftar pada Bursa Efek Indonesia (BEI) pada tahun 2017-2020. Sumber penelitian ini adalah sumber data sekunder. Teknik pengambilan sampel penelitian ini menggunakan metode purposive sampling, dengan populasi sebanyak 704 perusahaan. Kriteria sampel yang digunakan sebagai berikut menerbitkan 
Owner: Riset \& Jurnal Akuntansi

e-ISSN : 2548-9224 | p-ISSN : 2548-7507

Volume 6 Nomor 1, Januari 2022

DOI : https://doi.org/10.33395/owner.v6i1.588

laporan keuangan tahunan per tanggal 31 Desember periode 2017-2020 berturut-turut, perusahaan manufaktur yang memiliki kelengkapan data berkaitan dengan variabel-variabel yang digunakan dalam penelitian ini, laporan keuangan yang menggunakan mata uang Rupiah selama periode 2017-2020.Maka jumlah sampel terakhir pada penelitian ini yaitu 376.

Tabel 1. Seleksi Sampel Penelitian

\begin{tabular}{|c|c|c|c|c|c|c|}
\hline No & Kriteria & 2017 & 2018 & 2019 & 2020 & Total \\
\hline $\begin{array}{l}\text { Popr } \\
\text { Indo }\end{array}$ & $\begin{array}{l}\text { lasi : Perusahaan Manufaktur yang terdaftar pada Bursa Efek } \\
\text { nesia (BEI) selama tahun 2017-2020 }\end{array}$ & 176 & 176 & 176 & 176 & 704 \\
\hline 1. & $\begin{array}{l}\text { Perusahaan yang tidak menerbitkan laporan keuangan tahunan } \\
\text { per tanggal } 31 \text { Desember periode 2017-2020 berturut-turut. }\end{array}$ & (51) & (51) & (51) & (51) & (204) \\
\hline 2. & $\begin{array}{l}\text { Perusahaan Manufaktur yang tidak memiliki kelengkapan data } \\
\text { berkaitan dengan variabel-variabel yang digunakan dalam penelitian in }\end{array}$ & (3) & (3) & (3) & (3) & (12) \\
\hline & $\begin{array}{l}\text { Laporan keuangan yang tidak menggunakan mata uang Rupiah } \\
\text { selama periode } 2017-2020 .\end{array}$ & (28) & (28) & (28) & (28) & (112) \\
\hline Jun & llah Sampel & 94 & 94 & 94 & 94 & 376 \\
\hline
\end{tabular}

Sumber : Idx, data olahan 2021

Tabel 2. Definisi Operasional dan Pengukuran Variabel

\begin{tabular}{|c|c|c|}
\hline Variabel & Definisi Operasional & Pengukuran \\
\hline $\begin{array}{l}\text { Kualitas Laba } \\
\text { (Y) }\end{array}$ & $\begin{array}{l}\text { Laba merupakan bagian informasi dalam laporan keuangan } \\
\text { yang menjadi perhatian bagi pengguna informasi laporan } \\
\text { keuangan. Informasi tentang laba dapat menjadi ukuran } \\
\text { keberhasilan suatu perusahaan.Informasi laba juga dapat } \\
\text { digunakan sebagai indikator kinerja (Ginting, 2017). }\end{array}$ & Quality of Income : $\frac{\text { Arus Kas Operasi }}{\text { EBIT }}$ \\
\hline $\begin{array}{l}\text { Leverage } \\
\quad(\mathrm{X} 1)\end{array}$ & $\begin{array}{l}\text { Leverage adalah penggunaan aktiva dan sumber dana oleh } \\
\text { perusahaan yang memiliki biaya tetap (beban tetap) berarti } \\
\text { sumber dana yang berasal dari pinjaman karena memiliki } \\
\text { bunga sebagai beban tetap dengan maksud agar meningkatkan } \\
\text { keuntungan potensial pemegang saham (Sjahrial, 2009:147). }\end{array}$ & DAR: $\frac{\text { Total Hutang }}{\text { Total Aset }}$ \\
\hline $\begin{array}{l}\text { Likuiditas } \\
\text { (X2) }\end{array}$ & $\begin{array}{l}\text { Likuiditas (liquidity ratio) merupakan rasio yang } \\
\text { menggambarkan atau mengukur kemampuan perusahaan dalam } \\
\text { memenuhi kewajiban (utang) jangka pendek. Artinya apabila } \\
\text { perusahaan ditagih, perusahaan akan mampu untuk memenuhi } \\
\text { utang tersebut terutama utang yang sudah jatuh tempo (Kasmir, } \\
\text { 2014: 129) }\end{array}$ & Quick Ratio : $\frac{\text { Current Assets - Inventory }}{\text { Current Liability }}$ \\
\hline $\begin{array}{l}\text { Profitabilitas } \\
\text { (X3) }\end{array}$ & $\begin{array}{l}\text { Rasio Profitabilitas (Profitability Ratio) adalah perbandingan } \\
\text { yang digunakan untuk mengukur kemampuan perusahaan } \\
\text { dalam menghasilkan laba (Sudana, 2012: 22). }\end{array}$ & ROA : $\frac{\text { Laba Setelah Pajak }}{\text { Total Asset }}$ \\
\hline $\begin{array}{l}\text { Konservatisme } \\
\text { (X4) }\end{array}$ & $\begin{array}{l}\text { Konservatisme adalah reaksi yang cenderung mengarah pada } \\
\text { sikap kehati-hatian atau disebut prudent reaction dalam } \\
\text { menghadapi ketidakpastian yang melekat dalam perusahaan } \\
\text { dan melingkupi aktivitas bisnis dan ekonomi untuk mencoba } \\
\text { memastikan bahwa kettidakpastian dan risiko inheren yang } \\
\text { menjadi ancaman dalam lingkungan bisnis sudah cukup } \\
\text { dipertimbangkan (Oktomegah, 2012). }\end{array}$ & $\mathrm{CON}_{\mathrm{ACC}}=\frac{\text { NIit }- \text { CFOit }}{\text { TA }} \times(-1)$ \\
\hline $\begin{array}{l}\text { Ukuran } \\
\text { perusahaan } \\
\text { (X5) } \\
\end{array}$ & $\begin{array}{l}\text { Ukuran perusahaan merupakan skala ukuran besar kecilnya } \\
\text { sebuah perusahaan yang dapat dinilai maupun ditunjukan } \\
\text { dengan total aset (Diannita \& Nazar, 2020). }\end{array}$ & Size $=$ Ln $($ Total Aset $)$ \\
\hline
\end{tabular}

Sumber: Jurnal Publikasi Sinta dan Garuda

\section{Teknik Analisis Data}

\section{Analisis Statistik Deskriptif}

Analisis statistik deskriptif memberikan gambaran atau deskriptif suatu data yang dilihat dari nilai rata-rata (mean), standar deviasi, maksimum, minimum. Untuk memberikan gambaran mengenai analisis statistik deskriptif (Ghozali, 2018). 


\section{Uji Normalitas}

Uji normalitas bertujuan untuk menguji apakah dalam model regresi, variabel pengganggu atau residual memiliki distribusi normal. Data diatribusikan normal jika nilai signifikannya lebih dari 0,05 atau $5 \%$ hasil tersebut dapat dikatakan normal, begitupun sebaliknya (Ghozali, 2018:160). Uji normalitas pada penelitian ini digunakan analisis statistik yaitu dengan menggunakan nilai Zskewness dan Zkurtosis dengan alpha 5\%.

\section{Pengujian Asumsi Klasik}

\section{Uji Multikoleniaritas}

Uji multikolinieritas bertujuan untuk mengetahui apakah dalam model regresi menemukan variabel bebas atau korelasi antar variabel independen .Nilai cut-off yang digunakan adalah untuk nilai toleransi 0,10 atau nilai VIF lebih besar dari 10 (Ghozali, 2016).

\section{Uji Heteroskedastisitas}

Uji heteroskedastisitas merupakan variabel residual yang berbeda pada semua pengamatan model regresi. Penelitian ini menggunakan uji glejser. Jika nilai signifikansi lebih besar dari 0,05 berarti tidak terjadi heteroskedastisitas. Jika nilai signifikansi lebih kecil dari 0,05 berarti telah terjadi heteroskedastisitas.

\section{Uji Autokorelasi}

Uji autokorelasi memeriksa apakah ada korelasi dalam model regresi linier antara kesalahan pengganggu pada periode $t$ dan kesalahan pengganggu pada periode t-1 (sebelumnya). Jika ada korelasi maka disebut masalah autokorelasi (Ghozali, 2011: 110). Dalam penelitian ini, uji Durbin-Watson (DW test) digunakan untuk memeriksa tanda-tanda autokorelasi.

\section{Uji Regresi Linier Berganda}

Analisis regresi linear berganda merupakan analisis tentang hubungan antara satu variabel dependen dengan dua atu lebih variabel independen (Ghozali, 2018). Persamaan yang akan diuji adalah :

$$
\mathrm{QI}=\boldsymbol{a}+\beta 1 D A R+\beta 2 Q R+\beta 3 R O A+\beta 4 C O N \_A C C+\beta 5 S I Z E+\boldsymbol{e}
$$

Keterangan :

$\begin{array}{ll}Q I & : \text { Kualitas laba } \\ a & : \text { Konstanta } \\ \text { DAR } & : \text { Leverage } \\ \text { QR } & : \text { Likuiditas }\end{array}$

$\begin{array}{ll}\text { CON_ACC } & : \text { Konservatisme } \\ \text { SIZE } & : \text { Ukuran Perusahaan } \\ e & : \text { Standar error }\end{array}$

\section{Uji Kelayakan Model}

UJI F

Uji F bertujuan untuk mengetahui apakah variabel independen variable independen) secara bersamasama mempengaruhi variable dependen (Ghozali, 2016;96).Dalam penelitian ini digunakan tingkat signifikansi 0,05 .

\section{Uji Koefisiens Determinasi (R2)}

Uji Koefisien determinasi R2 pada dasarnya mengukur kemampuan model dalam menjelaskan variabel dependen. Nilai yang mendekati satu menunjukkan bahwa variabel independen menyediakan hampir semua informasi yang dibutuhkan untuk memprediksi perubahan variasi dependen (Ghozali, 2016; 95).

\section{Uji t}

Uji statistik t pada dasarnya menunjukkan seberapa besar pengaruh suatu variabel bebas dalam menjelaskan variabel terikat. Pengujian dilakukan dengan menggunakan signifikan level $0,05(\alpha=5 \%)$ (Ghozali, 2013:98). Jika nilai signifikan> 0,05 maka hipotesis ditolak (koefisien regresi tidak signifikan). Jika nilai signifikan $\leq 0,05$, terima hipotesis (koefisien regresi signifikan). 


\section{Analisis Statistik Deskriptif}

\section{HASIL}

Tabel 3. Analisis Statistik Deskriptif Sebelum Outlier

Descriptive Statistics

\begin{tabular}{lrrrrr}
\hline & $\mathrm{N}$ & Minimum & Maximum & Mean & Std. Deviation \\
\hline QI & 376 & $-173,896$ & 60,996 &, 50957 & 10,892177 \\
DAR & 376 &, 001 & 8,431 &, 57802 &, 785500 \\
QR & 376 &,- 713 & 13,044 & 1,54107 & 1,619570 \\
ROA & 376 & $-1,050$ & 1,000 &, 05544 &, 165958 \\
CON_ACC & 376 & $-66,155$ & 1,698 &,- 26088 & 3,624243 \\
SIZE & 376 & 22,610 & 32,726 & 28,28984 & 1,494566 \\
Valid N (listwise) & 376 & & & &
\end{tabular}

Sumber: Output SPSS 26

Berdasarkan tabel 3 menyatakan bahwa hasil analisis statistik deskriptif sebelum outlier dengan variabel dependen kualitas laba (QI), variabel independen leverage (DAR), likuiditas (QR), profitabilitas (ROA), konservatisme (CON_ACC) dan ukuran perusahaan (Size). Dengan jumlah sampel yang digunakan pada awal penelitian ditunjukkan dengan $(\mathrm{N})$ sebesar 376 perusahaan.

Tabel 4. Analisis Statistik Deskriptif Sesudah Outlier

Descriptive Statistics

\begin{tabular}{lcrrrr}
\hline & $\mathrm{N}$ & Minimum & Maximum & Mean & Std. Deviation \\
\hline QI & 326 & $-4,275$ & 4,647 &, 77353 & 1,244128 \\
DAR & 326 &, 001 & 8,431 &, 56513 &, 807446 \\
QR & 326 &,- 713 & 13,044 & 1,55473 & 1,582792 \\
ROA & 326 & $-1,050$ & 1,000 &, 05714 &, 160573 \\
CON_ACC & 326 & $-66,155$ & 1,698 &,- 29592 & 3,890450 \\
SIZE & 326 & 24,188 & 32,726 & 28,26837 & 1,475519 \\
Valid N (listwise) & 326 & & & &
\end{tabular}

Sumber: Output SPSS 26

Berdasarkan tabel 4 menunjukkan hasil analisis statistik deskriptif dengan variabel dependen kualitas laba (QI), variabel independen leverage (DAR), likuiditas (QR), profitabilitas (ROA), konservatisme (CON_ACC) dan ukuran perusahaan (Size). Dengan jumlah sampel yang digunakan pada awal penelitian ditunjukkan dengan $(\mathrm{N})$ sebesar 376 perusahaan. Hasil data statistik deskriptif sesudah outlier diperoleh data yang ditunjukkan dengan $(\mathrm{N})$ sebanyak 326 perusahaan.

\section{Uji Normalitas}

Tabel 5. Uji Normalitas sebelum Outlier Descriptive Statistics

\begin{tabular}{lccccc}
\hline & N & \multicolumn{2}{c}{ Skewness } & \multicolumn{2}{c}{ Kurtosis } \\
\hline & Statistic & Statistic & Std. Error & Statistik & Std. Error \\
\hline Unstandrdized Residual & 376 & $-10,810$ &, 126 & 180,021 &, 251 \\
Valid N (listwise) & 376 & & & &
\end{tabular}

Sumber: Output SPSS 26

Berdasarkan tabel 5 dapat dilihat bahwa nilai skewness dan kurtosis lebih besar dari 1,96 . Nilai skewness sebesar -85,7936 > -1,96 dan nilai kurtosis sebesar 717,2151> 1,96. Maka hal ini bisa dikatakan bahwa data yang diteliti tidak berdistribusi normal sehingga perlu dilakukan outlier di data - data ekstrim. Berikut hasil uji normalitas setelah di outlier :

Tabel 6. Uji Normalitas setelah Outlier

Descriptive Statistics

\begin{tabular}{ccccc}
\hline $\mathrm{N}$ & \multicolumn{2}{c}{ Skewness } & \multicolumn{2}{c}{ Kurtosis } \\
\hline Statistic & Statistic & Std. Error & Statistik & Std. Error \\
\hline
\end{tabular}


Owner: Riset \& Jurnal Akuntansi

e-ISSN : 2548-9224 | p-ISSN : 2548-7507

Volume 6 Nomor 1, Januari 2022

DOI : https://doi.org/10.33395/owner.v6i1.588

\begin{tabular}{llllll}
\hline Unstandrdized Residual & 326 &,- 080 &, 135 &,- 211 &, 269 \\
Valid N (listwise) & 326 & & & & \\
\hline
\end{tabular}

Sumber: Output SPSS 26

Berdasarkan tabel 6 uji normalitas diatas, dapat dilihat bahwa nilai skewness dan kurtosis lebih kecil dari 1,96. Nilai skewness sebesar $-0,5926<1,96$ dan nilai kurtosis sebesar -0,7844 < 1,96. Maka hal ini dapat dikatakan bahwa data tersebut telah menunjukkan berdistribusi normal.

Uji Asumsi Klasik

Uji Multikolenieritas

Tabel 7. Uji Multikoleniaritas

\begin{tabular}{lccc}
\hline \multicolumn{1}{c}{ Variabel } & Tolerance & VIF & Kesimpulan \\
\hline DAR &, 919 & 1,088 & Tidak terjadi \\
QR &, 937 & 1,067 & Tidak terjadi \\
ROA &, 920 & 1,087 & Tidak terjadi \\
CON_ACC &, 986 & 1,014 & Tidak terjadi \\
SIZE &, 950 & 1,052 & Tidak terjadi \\
\hline
\end{tabular}

Sumber: Output SPSS 26

Berdasrkan tabel 7 Nilai tolerance variabel independen tidak ada yang kurang dari 0,10. Pada variabel DAR nilai tolerance sebesar 0,919>0,10; variabel QR nilai tolerance sebesar 0,937 $>0,10$; variabel ROA nilai tolerance sebesar 0,920>0,10; variabel CON_ACC nilai tolerance sebesar 0,986 > 0,10; dan variabel SIZE nilai tolerance sebesar 0,950>0,10; Hal yang sama juga terjadi pada nilai Variance Inflation Factor (VIF).

Dapat dilihat pada masing - masing nilai Variance Inflation Factor (VIF) pada variabel independen tidak ada yang lebih dari 10. Pada variabel DAR nilai VIF sebesar 1,088 < 10; variabel QR nilai VIF sebesar 1,067 < 10; variabel ROA nilai VIF sebesar 1,087 < 10 variabel CON_ACC nilai VIF sebesar 1,014 < 10; variabel SIZE nilai VIF sebesar 1,052 < 10; Sehingga dapat disimpulkan model regresi pada penelitian ini tidak ditemukan masalah multikolinearitas antar variabel independen.

\section{Uji Heteroskedastisitas}

Tabel 8. Uji Heterokedastisitas Sebelum Diobati

\begin{tabular}{lccc}
\hline Variabel & Sig. & Standar & Kesimpulan \\
\hline DAR &, 235 & $>0,05$ & Tidak terjadi \\
QR &, 001 & $>0,05$ & Terjadi \\
ROA &, 623 & $>0,05$ & Tidak terjadi \\
CON_ACC &, 351 & $>0,05$ & Tidak terjadi \\
SIZE &, 000 & $>0,05$ & Terjadi \\
\hline
\end{tabular}

Sumber: Output SPSS 26

Berdasarkan tabel 8 hasil uji diatas dapat dijelaskan bahwa pengujian heteroskedastisitas terdapat 2 variabel yang diperoleh nilai signifikansi < 0,05 yang berarti model regresi mengadung heterokedastisitas. Maka perlu adanya transformasi variabel untuk mengobati adanya heterokedastisitas. Hasil uji heterokedastisitas yang sudah diobati :

Tabel 9. Uji Heterokedastisitas Sesudah Diobati

\begin{tabular}{lccc}
\hline Variabel & Sig. & Standar & Kesimpulan \\
\hline DAR &, 811 & $>0,05$ & Tidak terjadi \\
LAG_QR &, 250 & $>0,05$ & Tidak terjadi \\
ROA &, 727 & $>0,05$ & Tidak terjadi \\
CON_ACC &, 605 & $>0,05$ & Tidak terjadi \\
LAG_SIZE &, 756 & $>0,05$ & Tidak terjadi \\
\hline
\end{tabular}

Sumber: Output SPSS 26 
Berdasarkan tabel 9 hasil uji diatas dapat dijelaskan bahwa pengujian heteroskedastisitas menggukan uji glejser diperoleh nilai signifikansi masing-masing variabel diatas 0,05. Dapat dapat disimpulkan bahwa model regresi tidak terjadi heteroskedastisitas.

\section{Uji Autokorelasi}

\begin{tabular}{cccccc}
\hline Model & $\mathrm{R}$ & $\mathrm{R}^{2}$ & Adj R Square & Std. Error of the Estimate & Durbin-Watson \\
\hline 1 &, $274^{\mathrm{a}}$ &, 075 &, 060 & 1,206752 & 2,090 \\
\hline
\end{tabular}

Sumber: Output SPSS 26

Berdasarkan tabel 10 hasil uji menyatakan bahwa diperoleh batas bawah (dl) sebesar 1,79139 dan batas atas (du) sebesar 1,84199 sehingga 4-du yaitu sama sebesar 2,15801 dan 4-dl sebesar 2,20861. Maka dapat diartikan bahwa $\mathrm{dl}<\mathrm{dw}<4$-du atau 1,79139 $<2,090<2,15801$ dimana posisi nilai Durbin Watson yaitu sebesar 2,090 terletak pada daerah tidak ada autokorelasi. Sehingga model regresi pada penelitian ini terbebas dari autokorelasi.

\section{Uji Kelayakan Model \\ Uji F}

Tabel 11. Uji F

\begin{tabular}{lccccc}
\hline \multicolumn{1}{c}{ Model } & Sum of Squares & df & Mean Square & F & Sig. \\
\hline Regression & 37,636 & 5 & 7,527 & 5,169 &, $000^{\mathrm{b}}$ \\
Residual & 464,544 & 319 & 1,456 & & \\
Total & 502,180 & 324 & & & \\
\hline
\end{tabular}

Sumber: Output SPSS 26

Berdasrkan tabel 11 menunjukkan bahwa diperoleh hasil nilai $\mathrm{F}$ hitungnya sebesar 5,169 dengan nilai signifikansinya yaitu sebesar 0,000 . Hal ini berarti nilai signifikansi lebih kecil dari 0,05 atau 5\% dan dapat dikatakan bahwa variabel independen dalam model regresi ini secara bersama-sama berpengaruh terhadap variabel dependen yaitu kualitas laba.

Uji Koefisien Determinasi (Adjusted R2)

Tabel 12. Uji Koefisien Determinasi (Adjusted R2)

\begin{tabular}{lcccc}
\hline Model & $\mathrm{R}$ & $\mathrm{R}$ Square & Adjusted R Square & Std. Error of the Estimate \\
\hline 1 &, $274^{\mathrm{a}}$ &, 075 & 060 & 1,206752 \\
\hline
\end{tabular}

Sumber: Output SPSS 26

Berdasarkan tabel 12 menunjukkan bahwa diperoleh hasil yaitu nilai Adjusted R Square (R2) sebesar 0,060. Hal ini berarti bahwa variabel dependen (QI) dapat dijelaskan secara keseluruhan oleh tiga variabel independen yaitu DAR, QR, ROA, CON-ACC, SIZE sebesar 6\%. Sedangkan $94 \%(100 \%-6 \%=94 \%)$ dijelaskan oleh variabel - variabel lainnya diluar model penelitian ini.

\section{Uji Regresi Linier Berganda}

Tabel 13. Uji Regressi Linier Berganda dan Uji Hipotesis

\begin{tabular}{|c|c|c|c|c|c|}
\hline \multirow[b]{2}{*}{ Model } & \multicolumn{2}{|c|}{ Unstandardized Coefficients } & \multirow{2}{*}{$\begin{array}{c}\text { Standardized Coefficients } \\
\text { Beta }\end{array}$} & \multirow[b]{2}{*}{$\mathrm{t}$} & \multirow[b]{2}{*}{ Sig. } \\
\hline & $\mathrm{B}$ & Std. Error & & & \\
\hline (Constant) & ,220 & 1,303 & & , 169 & ,866 \\
\hline DAR &,- 087 & ,085 &,- 057 & $-1,026$ & ,305 \\
\hline LAG_QR & ,040 & ,042 &, 050 & ,933 & ,352 \\
\hline $\mathrm{ROA}^{-}$ & ,950 & ,428 & 123 & 2,217 & 027 \\
\hline CON_ACC & 072 & 017 & 225 & 4,153 &, 000 \\
\hline LAG_SIZE & ,018 & ,046 & 021 & ,390 & ,697 \\
\hline
\end{tabular}

Sumber: Output SPSS 26

Berdasarkan pada tabel 13 maka dapat disusun persamaan regresi sebagai berikut :

$$
\mathrm{QI}=0,220-0,087 D A R+0,040 Q R+0,950 R O A+0,072 C O N_{-} A C C+0,018 S I Z E+e
$$




\section{Uji Hipotesis (Uji Statistik t)}

$\mathrm{H} 1$ : Leverage berpengaruh negatif terhadap kualitas laba

Berdasarkan tabel 13 menunjukan bahwa nilai t hitung variabel DAR sebesar -1,026 dengan nilai signifikan sebesar $0,305>0,05$. Hal ini beratikan bahwa leverage tidak berpengaruh terhadap kulitas laba. Sehingga untuk hipotesisi pertama (H1) ditolak.

$\mathrm{H} 2$ : Likuiditas berpengaruh positif terhadap kualitas laba

Berdasarkan tabel 13 menunjukan bahwa nilai t hitung variabel QR sebesar 0,933 dengan nilai signifikan sebesar $0,352>0,05$. Hal ini beratikan bahwa likuiditas tidak berpengaruh terhadap kulitas laba. Sehingga untuk hipotesisi pertama (H2) ditolak .

H3: profitabilitas berpengaruh positif terhadap kualitas laba.

Berdasarkan tabel 13 menunjukan bahwa nilai t hitung variabel ROA sebesar 2,217 dengan nilai signifikan sebesar $0,027<0,05$. Hal ini beratikan bahwa profitabilitas berpengaruh positif terhadap kulitas laba. Sehingga untuk hipotesisi pertama (H3) diterima.

H4 : Konservatisme berpengaruh positif terhadap kualitas laba

Berdasarkan tabel 13 menunjukan bahwa nilai t hitung variabel CON_ACC sebesar 4,153 dengan nilai signifikan sebesar $0,00<0,05$. Hal ini beratikan bahwa konservatisme berpengaruh positif terhadap kulitas laba. Sehingga untuk hipotesisi pertama (H4) diterima.

H5 : Ukuran perusahaan berpengaruh positif terhadap Kualitas Laba

Berdasarkan tabel 13 menunjukan bahwa nilai t hitung variabel SIZE sebesar 0,390 dengan nilai signifikan sebesar $0,697>0,05$. Hal ini beratikan bahwa ukuran perusahaan tidak berpengaruh terhadap kulitas laba. Sehingga untuk hipotesisi pertama (H5) ditolak.

\section{PEMBAHASAN}

\section{Pengaruh (DAR) Leverage terhadap kulitas laba}

Berdasarkan pengujian hipotesis pertama dapat menunjukan bahwa tidak adanya pengaruh leverage terhadap kualitas laba. Dikarenakan jika aset perusahaan lebih besar dana oleh hutang dari pada modalnya sendiri maka peran investor menurun, akibatnya dinilai tidak bisa menjaga keseimbangan keuangan pada pengelolaan dana antara jumlah modal yang tersedia menggunakan modal yang dibutuhkan. Perusahaan menggunakan hutang yang lebih besar akan berusaha menunjukkan kinerja yang baik agar memperoleh kepercayaan dari investor. Hal ini berdampak dikecenderungan manajemen melakukan tindakan manajemen laba dengan dilaporkan laba yg tinggi, akibatnya kualitas laba menjadi rendah. Hasil penelitian ini didukung dengan penelitian terdahulu yaitu : Dewi, Endiana \& Arizona (2020) leverage berpengaruh negatif terhadap kualitas laba dan Setiawan (2017) leverage tidak berpengaruh terhadap kualitas laba.

\section{Pengaruh (QR) Likuiditas tidak berpengaruh terhadap kulitas laba}

Berdasarkan pengujian hipotesis kedua dapat menunjukan bahwa tidak adanya pengaruh likuiditas terhadap nilai kualitas laba. Dikarenakan likuiditas perusahaan menunjukkan kemampuan perusahaan mendanai operasional perusahaan dan melunasi kewajiban jangka pendeknya (Arilaha, 2009:80). likuiditas menunjukkan bahwa perusahaan mampu untuk memenuhi kewajiban finansialnya dalam jangka pendek menggunakan dana lancar yang tersedia.Apabila likuiditas perusahaan terlalu rendah maka perusahaan tersebut berarti tidak mampu mengelola asset lancarnya semaksimal mungkin sehingga kinerja keuangan menjadi kurang baik dan kemungkinan ada manipulasi laba untuk mempercantik informasi laba tersebut. Hasil penelitian ini didukung dengan penelitian terdahulu yaitu : Ginting (2017) Likuiditas tidak berpengaruh terhadap kualitas laba, dan Setiawan (2017) likuiditas tidak berpengaruh terhadap kualitas laba.

\section{Pengaruh (ROA) Profitabilitas berpengaruh positif terhadap kulitas laba}


Berdasarkan pengujian hipotesis tiga dapat menunjukan bahwa berpengaruh positif profitabilitas terhadap nilai kualitas laba. Dikarenakan Perusahaan yang memiliki profitabilitas tinggi, maka laba yang didapatkan oleh perusahaan semakin tinggi. Hal ini akan membuat semakin menarik perhatian investor terhadap perusahaan karena dianggap menguntungkan bagi investor dalam melakukan investasi pada perusahaan tersebut Semakin besar return on asset (ROA) suatu perusahaan, semakin besar pula tingkat keuntungan yang dicapai oleh perusahaan tersebut. Maka bisa dikatakan juga perusahaan tersebut memiliki kualitas laba yang baik. Hasil penelitian ini didukung dengan penelitian terdahulu yaitu : Ardianti (2018); Kurniawan \& Suryaningsih (2018) membuktikan bahwa profitablilitas pengaruh positif terhadap kualitas laba.

\section{Pengaruh (CON_ACC) Konservatisme berpengaruh positif terhadap kulitas laba.}

Berdasarkan pengujian hipotesis keempat dapat menunjukan bahwa berpengaruh positif konservatisme terhadap nilai kualitas laba. Dikarenakan Konservatisme dapat melindungi investor dari kekeliruan menilai informasi laba yang tinggi namun tidak disajikan sesuai dengan keadaan yang sebenarnya (Putu dan Dewa 2014). Manajer memberitahukan informasi di dalam laporan keuangan bahwa mereka memakai kebijakan konservatisme sehingga laba yang dihasilkan lebih berkualitas karena prinsip tersebut mencegah perusahaan dalam membesarkan laba (Elen, 2013). Hasil penelitian ini didukung dengan penelitian terdahulu yaitu : Kurniawan \& Suryaningsih (2018) memiliki pengaruh positif secara signifikan terhadap kualitas laba.

\section{Pengaruh (SIZE) Ukuran perusahaan tidak berpengaruh terhadap kulitas laba.}

Berdasarkan pengujian hipotesis kelima dapat menunjukan bahwa tidak adanya pengaruh ukuran perusahaan terhadap nilai kualitas laba. Dikarenakan semakin kecil ukuran suatu perusahaan memiliki kualitas laba yang lebih tinggi. Perusahaan yang relatif kecil kinerjanya tidak akan terlalu dilihat oleh publik sehingga perusahaan tersebut akan melaporkan kondisi keuangannya dengan lebih leluasa, maka akan rentan menunjukkan informasi yang terkandung di dalamnya dan kurang transparan sehingga akan lebih banyak dalam melakukan manipulasi laba (Warianto dan Rusiti; 2014). Hasil penelitian ini didukung dengan penelitian terdahulu yaitu : Ginting (2017) ukuran perusahaan tidak berpengaruh terhadap kualitas laba.

\section{KESIMPULAN}

Penelitian ini bertujuan untuk menguji dan menganalisa pengaruh leverage, likuiditas, profitabilitas, konservatisme, dan ukuran perusahaan. Berdasarkan uji yang telah dilakukan memperoleh hasil bahwa leverage yang diukur dengan (DAR) tidak berpengaruh terhadap kulitas laba. Hal ini menunjukkan bahwa tingginya leverage dapat menurunkan kualitas laba, ukuran perusahaan yang diukur dengan (Size) tidak berpengaruh terhadap kulitas laba. Hal ini menunjukkan bahwa naik turunnya kualitas laba tidak diimbangi dengan tinggi atau rendahnya ukuran perusahaan dan likuiditas yang diukur dengan (QR) tidak memiliki pengaruh secara signifikan terhadap kulitas laba. Hal ini menunjukkan bahwa rendahnya likuiditas dapat menurunkan kualitas laba. Sedangkan profitabilitas yang diukur dengan (ROA) memiliki pengaruh positif terhadap kulitas laba. Hal ini menunjukkan bahwa tingginya profitabilitas dapat meningkatkan kualitas laba dan konservatisme yang diukur dengan (CON_ACC) memiliki pengaruh signifikan dengan arah positif terhadap kulitas laba Hal ini menunjukkan bahwa naik turunnya kualitas laba tidak diimbangi dengan tinggi atau rendahnya konservatisme.

\section{REFERENSI}

Abdullah, M. W., \& Suardi, S. 2017. Pengaruh Overvalued Equities Dan Earnings Management Terhadap Kualitas Laba Dengan Good Corporate Governance Sebagai Variabel Moderasi. Assets, 7(1), 86-103.

Aprillia, F., (2018, Vol 7, No 11). Pengaruh Perputaran Total Aset, Perputaran Piutang Dan Debt To Equity Ratio Terhadap Profitabilitas . Jurnal Ilmu dan Riset Manajemen, 1-22.

Arsita, M. A., \& Kristanti, F. T. (2019). Pengaruh Leverage, Profitabilitas, Kepemilikan Manajerial, Intensitas Modal Dan Ukuran Perusahaan Terhadap Konservatisme Akuntansi (Studi Empiris 
pada Perusahaan Sub Sektor Food and Beverages yang Terdaftar di Bursa Efek Indonesia

Periode 2014-2017). e-Proceeding of Management, 6(2), 3399-3410.

Ardianti, R. (2018). Pengaruh Alokasi Pajak Antar Periode, Persistensi Laba, Profatibilitas Dan

Likuiditas Terhadap Kualitas Laba. Jurnal Akuntansi, 88-136.

Brigham, E. F. (2006). Fundamental of Financial Management: Dasar-Dasar Manajemen Keuangan,Edisi 10. Jakarta: Salemba Empat.

Dermawan, S. (2009). Manajemen Keuangan, edisi 3. Jakarta: Mitra Wacana Media.

Diannita, T., \& Nazar, M. R. (2020). Pengaruh Ukuran Perusahaan, Intensitas Modal, Dan Frekuensi Pertemuan Komite Audit Terhadap Konservatisme Akuntansi (Studi Empiris pada Perusahaan Sub Sektor Food and Beverage yang terdaftar di Bursa Efek Indonesia selama periode 20142017) . e-Proceeding of Management, 7(2), 3270-3276

Eisenhardt, K. M. (1989). Agency Theory: An Assesment and Review. Academy of management , 5774.

Fahmi, Irham.2015. Pengantar Teori Portofolio dan Analisis Investasi.Bandung : Alfabeta

Ginting, S. (2017). Pengaruh Profitabilitas, Likuiditas Dan Ukuran Perusahaan Terhadap Kualitas Laba. Jurnal Wira Ekonomi Mikroskil, 227-236.

Gusti, D. M. (2020). Pengaruh Leverage, Investment Opportunity Set (Ios), Dan Mekanisme Gcg Terhadap Kualitas Laba . Jurnal Kharisma, 125-136.

Halim, A. d. (2009). Analisis Laporan Keuangan. Edisi 4. . UPP STIM YKPN: Yogyakarta.

Hakim, M. Z., \& Eksandy, A. 2019. Pengaruh Likuiditas, Leverage Dan Profitabilitas Terhadap Stock Price Pada Industri Manufaktur. Competitive Jurnal Akuntansi Dan Keuangan, 2(2), 66-84

Harahap, S. S. (2007). Analisis Kritis Atas Laporan Keuangan. Jakarta: PT Raja Grafindo Persada.

Ghozali, I. (2011). Aplikasi Analisis Multivariate Dengan Program SPSS. Semarang : Badan Penerbit Universitas Diponegoro.

Ghozali, I. (2013). Aplikasi Analisis Multivariate dengan Program IBM SPSS 21 Update PLS Regresi. Semarang: Badan Penerbit Universitas Diponegoro.

Ghozali, I. (2016). Aplikasi Analisis Multivariete Dengan Program (IBM SPSS). Edisi 8. Semarang : Badan Penerbit Universitas Diponegoro.

Ghozali, I. (2018). Aplikasi Analisis Multivariate Dengan Program IBM SPSS 25 Edisi 9. Semarang: Badan Penerbit Universitas Dipenogoro.

Irawati, D. E. (2012). Pengaruh Struktur Modal, Pertumbuhan Laba, Ukuran Perusahaan dan Likuiditas Terhdap Kualitas Laba . Accounting Analysis Journal, 1-6.

Jensen, M. C. (1976). Theory of The Firm: Managerial Behavior, Agency Cost and Ownership Structure. Journal of Financial Economics 3, 305-360.

Jogiyanto. (2000). Sistem Informasi Akuntansi Berbasis Komputer. Edisi ketiga. Yogyakarta : BPFE

Kasmir. (2014). Analisis Laporan Keuangan, cetakan ke-7. Jakarta: PT Raja Grafindo Persada.

Kieso, D. E. (2015). Financial Accounting IFRS Edition. USA: Wiley.

Made, S. I. (2012). Manajemen Keuangan Perusahaan Teori dan Praktik. Jakarta: Erlangga.

Marsela, S. Y., \& Maryono, M. 2017. Pengaruh Good Corporate Governance, Leverage, Profitabilitas, Dan Ukuran Perusahaan Terhadap Kualitas Laba (Studi Pada Perusahaan Publik Yang Termasuk Dalam Pemeringkatan Cgpi Tahun 2013-2016). Dinamika Akuntansi Keuangan Dan Perbankan, 6(1).

Metalia, s. y. (2021). penerapan Earning Management, Intensitas Modal, Lavarage, dan GCG Terhadap Kualitas Laba. Competitive Jurnal Akuntansi dan Keuangan, 36-46.

Oktomegah, C. (2012). Faktor-Faktor yang Mempengaruhi Penerapan Konservatisme Pada Perusahaan Manufaktur di BEI. Jurnal Ilmiah Mahasiswa Akuntansi., 36-42.

Pralita, P. (2021). The Influence of Corporate Governance Mechanism, Accounting Conservatism,And Company Size on Earnings Quality. Journal of Economics, Finance and Management Studies, 26-34.

Putri, C. A. (2020, April 8). CNBC Indonesia. Diambil kembali dari CNBC Indonesia.com: https://www.cnbcindonesia.com/market/20200108173634-17-128650/ini-hasil-lengkapinvestigasi-pendahuluan-bpk-soal-jiwasraya

Putri, M. \&. (2015). Pengaruh Audit Tenure, Audit Fee, Rotasi Audit, dan Spesialisasi Auditor Terhadap Kualitas Audit. Skripsi Fakultas Ekonomi dan Bisnis Universitas Muhammadiyah Surakarta, Surakarta.

Riyanto., B. (2001). Dasar-dasar Pembelanjaan Perusahaan. Yogyakarta: BPFE. 
Owner: Riset \& Jurnal Akuntansi

e-ISSN : 2548-9224 | p-ISSN : 2548-7507

Volume 6 Nomor 1, Januari 2022

Ross, S. A. 1978. Some Notes On Financial Incentive-Signalling Models, Activity Choice And Risk Preferences. The Journal Of Finance, 33(3), 777-792.

Setiawan, B. r. (2017). Pengaruh ukuran perusahaan, profatibilitas, Likuiditasdan Laverage terhadap kualitas laba pada perusahaan manufaktur industri barang konsumsi yang terdaftar diBEI. MENARA ilmu, 36-46.

Sugiyono. (2013). Metodelogi Penelitian Kuantitatif, Kualitatif Dan R\&D. Bandung: ALFABETA.

Suryaningsih, C. K. (2018). Pengaruh Konservatisme Akuntansi, Debt To Total Assets Ratio, Likuiditas Terhadap Kualitas Laba. Jurnal Ekonomi, Manajemen, Akuntansi, 163-180.

Susanti. (2017). Pengaruh Leverage, Likuiditas, Ukuran Perusahaan, dan Kualitas Audit Terhadap Kualitas Informasi Laporan Keuangan. Jurnal Fakultas Ekonomi Universitas Sarjanawiyata Tamansiswa Vol. 1 No 1., 36-46.

Utami, T dan Kusuma, I. 2017. "Detirminan Kualitas Laba pada Isu Pengadopsian Internasional Financial Reporting Standard: Data dari Asia". Jurnal Akuntansi dan Investasi, Vol. 18, No.1.

Wati, G. P., \& Putra, I. W. 2017. Pengaruh Ukuran Perusahaan, Leverage, Dan Good Corporate Governance Pada Kualitas Laba. E-Jurnal Akuntansi, 137-167.

Watts Ross L. dan Jerold L. Zimmerman (1986). Positive Accounting Theory. USA: Prentice-Hall.

Warianto dan Rusiti. 2014. Pengaruh Ukuran Perusahaan, Struktur Modal, Likuiditas, dan Investmenr Opportunity Set (IOS) terhadap Kualitas Laba. Modus Journals. Vol. 26 No. 1.

Zulman \& Abbas. (2019). Pengaruh Ukuran Perusahaan, Struktur Modal, Likuiditas, Investment Opportunity Set (Ios), Dan Profitabilitas Terhadap Kualitas Laba (Perusahaan Makanan Dan Minuman Yang Terdaftar Di Bursa Efek Indonesia Tahun 2013-2017). Jurnal Akuntansi \& Keuangan Vol. 3 No2. 